\title{
The Influence of Child Labour on Academic Achievement of Primary School Pupils in Suba and Homa-Bay Districts, Kenya
}

\author{
Susan Nduta Ligeve \\ Moi University, Eldoret \\ Email: suligeve@gmail.com \\ Dr. Moses W. Poipoi \\ Masinde Muliro University of Science and Technology, Kakamega \\ Email: wesangulamp@yahoo.com
}

Accepted: July 5, 2012 Published: August 09, 2012

Doi:10.5296/ijld.v2i4.2214 URL: http://dx.doi.org/10.5296/ijld.v2i4.2214

\begin{abstract}
This causal-comparative study investigated the effects of child labour on academic achievement of primary school pupils in Suba and Homa-Bay districts in Kenya. The participants of this study were Class 7 pupils drawn from 12 schools in these two districts. A total of 333 pupils that is, 171 boys and 162 girls participated in the study. The academic achievement scores, which were extracted from the schools' end-term examination records, were used to compare the participants on the dependent variable. The results of this study showed that pupils who were involved in child labour had a significantly lower academic achievement mean score than those not involved. The results also indicated that boys not involved had a significantly higher academic achievement mean score than girls not involved. Furthermore, boys involved in child labour activities had a significantly higher academic mean score than girls involved in child labour activities. It was concluded that there were child labour and gender effects on academic achievement of primary school pupils in Suba and Homa Bay districts. This study recommends that school pupils should not engage in fishing activities.
\end{abstract}

Key Words; Child labour, Academic Achievement, Gender 


\section{Introduction}

Child labour is a global problem, and its elimination is being called for in the world. According to a recent International Labour Organisation (ILO) report, it was estimated that there are 250 million children between the ages of 5 and 14 years working in Developing countries - 120 million are working full time while 130 million are working part time (Chakravarthi, 1997, January 26). These children are involved in such activities like picking coffee or tea regardless of whether it is a school term or holiday (Staff, 2000, October 30). They are also involved in fishing activities, salt harvesting, and sugar cane cutting. Gugler and Gilbert (1992) reported that child labour is a serious concern because large numbers of children are trapped in highly exploitative and abusive employment relations such as domestic work and bonded labour. In the dangerous and hazardous categories of work, brick making, commercial sex, mining, and carpet making are the most cited. Bequele and Boyden (as cited in Gugler \& Gilbert 1992) reports that many children work for excessively long hours and do not receive adequate nutrition, health care, and education.

In Kenya, the exact number of children in the labour market is not known. This is because no statistics exist to show how many children are in the labour market. What exist are mere estimations from individuals. For instance, the ILO program co-ordinator claimed that there were three million children in the labour market (Staff, 1997, July 29). The Minister for Labour while addressing 1998 Labour Day, reported that three million children of school going age were out of school and the labour force would grow to 16 million by the year 2010 (Staff, 1998, May 2). More recently, the minister said that there were more than four million Kenyan children engaged in child labour. This figure puts the country in sixth position in Africa in the prevalence of the practice of child labour. The minister attributed the problem to rising levels of poverty, population explosion and unemployment. He further added that the introduction of cost sharing in primary education 15 years ago had seen enrolment of children in schools drop from 95 to 75 per cent. This he noted has compounded the problem of child labour (Njue, 2000, July 28). Otieno (1995) states that some child labourers in Kenya hawk or beg a long the streets, while others work in agricultural and domestic sectors. Moreover some of these children work in the fisheries, quarry, forestry, and in the commercial sex industry. Two surveys in Homa Bay and Suba districts by Training and Advocacy for Community Initiative \{TRACOI; as cited in Staff, 1998, July 29\} and Homa Bay District Children Advisory Committee \{HDCAC; as cited in Oloo and Ojwang, 1994\} showed that school children were heavily involved in fishing activities. The surveys indicated that children participated in these activities to the detriment of their health and education. The literature review conducted in this study did not find any studies in Kenya, which have investigated the effects of fishing activities on academic achievement of primary school pupils. This study therefore concentrated on those children who work in the fishing industry. Onyango's study (as cited in Shah \& Cantwell, 1985) points out that child labour can be seen as both participatory-beneficial and exploitative activity. As participatory-beneficial activity, child labour is a way children can share in the redistribution of wealth by earning wages. Onyango adds that in the agricultural societies, it could even be the only means of ensuring a balanced diet for the whole family. Furthermore, 
Onyango argues that in the work process, children can learn skills and social values that schools may not offer. A working child she asserts is not idle and thus is less likely to drift away and involve himself/herself in criminal and anti-social activities. On the contrary, Kayongo-Male and Walji (1984) argue that during the work process the child may learn deviant behaviours like lying, stealing, and even abusive language especially when working with careless adults who treat children like adults.

As an exploitative activity, Onyango argues that child labour is a way by which children under the age of 16 years are exposed to conditions of work that may be harmful to their physical, emotional, mental, and moral welfare. In addition, Onyango notes that observations made among children working in factories show that work can stunt development during the period of growth, prevents children from going to school, and creates cheap labour. The current study investigated whether or not fishing activities have an influence on academic achievement of primary school pupils. The child presence in the labour market carries many implications. The most important being his absence from school as observed by Dogramaci (as cited in Shah \& Cantwell, 1985). Dogramaci notes that most ILO studies in different countries like Kenya, Thailand, India, and Bangladesh have shown that most working children do not go to school. Dogramaci asserts that lack of schooling perpetuates a bleak and hopeless status quo, barring the way to any sort of advancement, or better life. He adds that those who work and go to school may not succeed in education. This is because the long hours spent on the job result in fatigue, listlessness, and lack of concentration in class. This in turn leads to poor performance, failure, and high school drop out rates. However, such claims lack empirical evidence to support them. In the absence of this empirical evidence, people may not make informed decisions about the effects of child labour on education. This study aimed at providing such evidence to support or refute the claims that child labour has negative effects on education.

There are reports that from early age, boys and girls are taught different skills and are assigned gender specific roles. In many cultures, female children have a lower ranking than male children and are generally denied educational opportunities \{Government of Kenya, 1992\}. Studies also show that when parents are faced with financial constraints, especially in rural areas, they give priority to boys' education. Implementation of cost sharing in education has surely made it very expensive for parents to educate their children. Given this tendency of parents to favour boys in education, girls are prone to be disadvantaged. Castle (as cited in Olweya, 1996) observed that some parents regarded girls as intrinsically inferior to boys. Because of this belief girls are more likely to drop out of school when financial difficulties exist in families. Castle adds that domestic child labour keeps more girls than boys out of school and that many parents in many developing countries will give preference to boys' education and fail to appreciate the value of education for girls. Instead, they see the value of girl's labour in house and collecting firewood and water.

United Nations Educational Scientific and Cultural Organisation (UNESCO, 1975) states that girls clean the house, cook, fetch water, and help care for younger children especially when a mother dies, falls ill or is overworked. With all these chores done, girls may be too exhausted to 
concentrate on their studies, leading to poor performance. Kayongo-Male and Onyango (1991) notes that in rural areas, female children are often more burdened by after school duties than male children. They attribute this to the fact that most of the after school duties are largely female roles. Moreover, a female child's performance in education may not be as highly valued as that of a male child. Thus, while the male child is seen as needing time to do homework, this may seem to parents to be of secondary importance for the female child.

\section{Methodology}

The study was carried out in two districts, which border Lake Victoria. These were Homa Bay and Suba districts. In these districts, Lake Victoria provides a good natural resource base for fishing. Majority of fishermen still use traditional methods of fishing. The catch is still mainly meant for subsistence. However, the introduction of Nile perch species into the lake has improved the industry, by providing both local and foreign markets with fish fillet. This study was a causal-comparative research investigating the effects of fishing activities on academic achievement by comparing the end term results of pupils who were involved in fishing activities to the results of those who were not involved in fishing activities. The dependent variable was academic achievement of primary school pupils while the independent variable was fishing activities. From the two districts, that is Homa Bay and Suba the researcher selected two beaches conveniently. This was done with the assistance of the District Education Officers (D.E.Os) of the two districts. The beaches were only selected if they were accessible. From Homa-Bay district, Oginga and Ngegu beaches were selected. From Suba district, Luanda Rombo and Kitawa beaches were selected. There were eight primary schools close to Luanda Rombo beach while there were six primary schools close to Kitawa beach. Primary Schools close to Ngegu beach were seven, while those close to Oginga beach were five. Once identified, the names of the primary schools close to each beach were written on pieces of paper. The papers were folded, put in a container, and were mixed thoroughly. Then three schools were randomly picked from each beach and used for the study. A total of 12 schools were selected. A total of 12 primary schools were involved in the study. From these primary schools the Class 7 pupils participated in the study. This short questionnaire was distributed to pupils in Class 7 chosen for the study. A total of 333 pupils completed the questionnaire used in this study. Of this, 228 were pupils involved, and 105 were pupils not involved in fishing activities. In this study both descriptive and inferential statistics were used in data analyses. The descriptive statistics used were means, standard deviations, frequencies and percentages. The inferential statistics used was t-test for independent samples. The statistical level of significance was set at .05. 
Results and Discussion

The first null hypothesis tested in this study was derived from the first research hypothesis. This null hypothesis stated that there was no significant difference in academic achievement between pupils who were involved and those who were not involved in fishing activities. To test this hypothesis the mean score of 228 pupils who were involved in fishing activities was compared to the mean score of 105 pupils who were not involved in fishing activities. The t-test for independent samples was used in the comparison. The Result of t-test Comparing Academic Achievement of Pupils Involved and Pupils_Not Involved in Fishing Activities is shown in table 1.

Table 1: A t-test Comparing Academic Achievement of Pupils Involved and Pupils Not Involved in Fishing Activities

\begin{tabular}{llcccc}
\hline Involvement in Fishing & $\mathrm{n}$ & $\mathrm{M}$ & $\mathrm{SD}$ & $\mathrm{t}$ & $\mathrm{df}$ \\
Pupils Involved & 228 & 311.9 & 48.5 & \\
\hline Pupils Not involved & 105350.4 & $57.4 \quad \begin{array}{c}-6.4^{*} \\
* \mathrm{p}<.05\end{array}$
\end{tabular}

The result of t-test showed that there was a statistically significant difference between the two groups of pupils in academic achievement, $\underline{t}(331)=-6.4, \underline{p}<.05$. It was concluded that fishing activities had significant effect on academic achievement of the pupils who were involved in these activities. This concurs with the HDCAC survey (as cited in Oloo \& Ojwang', 1994) that found high rates of absenteeism among pupils in the area especially during the long rain season, which normally begins in May. It is at this time when most parents remove their children from school to participate in fishing activities, either to supplement the family income or to assist in the family business.

The second null hypothesis tested in this study was derived from the second research hypothesis. This null hypothesis stated that there was no significant difference in academic achievement between boys who were involved and girls who were involved in fishing activities. To test this hypothesis the mean score of 126 boys who were involved in fishing activities was compared to the mean score of 102 girls who were involved in fishing activities. The t-test for independent samples was used in the comparison. The result of the comparison is presented in Table2. 
Table 2: A t-test Comparing Academic Achievement of Girls and Boys Involved in Fishing Activities.

\begin{tabular}{lllllll}
$\begin{array}{l}\text { Gender } \\
\text { Boys }\end{array}$ & $\underline{\mathrm{n}}$ & $\underline{\mathrm{M}}$ & $\underline{\mathrm{SD}}$ & $\underline{\mathrm{t}}$ & $\underline{\mathrm{df}}$ & \\
\hline Girls & 126 & 324.4 & 48.2 & & \\
\hline & 102 & 296.4 & 44.2 & $\mathrm{a}^{*} \underline{\mathrm{P}}<.05$ \\
\hline
\end{tabular}

The result of t-test showed that there was a statistically significant difference between boys who were involved and girls who were involved in fishing activities in academic achievement, $\underline{\mathrm{t}}(226)=4.5, \underline{\mathrm{p}}<.05$. It was concluded that the academic achievement mean score of boys who were involved in fishing activities was higher than for girls who were involved in fishing activities. This agrees with the UNICEF report of 1992 which noted that greater demands are made on female children to assist with house hold chores, to care for the young siblings, fetch water, and collect firewood. The report further adds that these duties may depress female performance in academics. Kayongo-Male and Onyango (1991) also observed that female children are often burdened by after school duties than male children. They attributed this to the fact that after school duties are largely performed by females. With all these chores done, girls may be too exhausted to concentrate on their studies, leading to poor performance.

The third null hypothesis tested in this study was derived from the third research hypothesis. This null hypothesis stated that there was no significant difference in academic achievement between boys and girls who were not involved in fishing activities. To test this hypothesis the mean score of 36 boys who were not involved in fishing activities was compared to the mean score of 69 girls who were not involved in fishing activities. The t-test for independent samples was used in the comparison. The result of the comparison is presented in Table 3.

Table 3: A_t-test Comparing Academic Achievement of Boys and Girls Not Involved in Fishing Activities.

Gender

Boys $\quad \frac{\underline{\mathrm{n}}}{36} \quad \underline{\underline{\mathrm{M}}} \quad \underline{378.853 .4} \underline{\underline{\mathrm{SD}}} \quad \underline{\mathrm{t}} \quad \underline{\mathrm{df}}$

$3.9^{*} \quad 103$

Girls $\quad 69 \quad 335.653 .9 \quad * \mathrm{p}<.05$


The result of t-test showed that there was a statistically significant difference between boys and girls who were not involved in fishing activities in academic achievement, $\underline{\mathrm{t}}(103)=3.9, \underline{\mathrm{p}}<$ .05. It was concluded that the academic achievement mean score of boys who were not involved in fishing activities was higher than for girls who were not involved in fishing activities. This concurs with the observations made by Kayongo-Male and Onyango (1991) that a female child's performance in education may not be as highly valued as that of a male child. Thus, while a male child is seen as needing time to do homework, homework may seem to parents to be of secondary importance for the female child. In many countries the school day for girls is long because they have to come early from school and accomplish some domestic chores. Sometimes they leave for school later than boys for the same reason. (Kadzamira, as cited in Kamotho, 2000, November 11).

\section{Conclusion}

The main objective of the study was to determine whether fishing activities had an influence on pupils' academic achievement. The findings of the study revealed that there was significant difference in the academic achievement of pupils who were involved and those who were not involved in fishing activities, and that the academic achievement of boys involved was significantly higher than that of girls involved in fishing activities. This leads to the conclusion that fishing activities have an effect on academic achievement, and that the effect is moderated by gender. Given the above findings, parents and the community at large should be made aware of the detrimental effects of fishing activities on academic performance of their children. Parents and the society at large should reconsider their stand on girls' education. Girls should be relieved from participating in fishing activities and some of those after school duties. This will enable them to compete on an equal ground with boys. International bodies like UNICEF could use the findings of this study to intensify their campaigns against child labour by pointing out the negative effects of fishing activities on academic achievement.

\section{References}

Chakravarthi, R. (1997, January 26). Hope as ILO acts on child labour. Sunday

Times. Nairobi: Sunday Times Publishers, p. 9.

Government of Kenya/UNICEF. (1992). Children and Womein

Kenya. A situation analysis. Nairobi: GoK/UNICEF.

Gugler, J. (1988). The Urbanisation of the Third World. New York: Oxford

University press. 
Gugler, J. \& Gilbert, A. (1992). Cities, poverty and development. urbanisation in the Third World. New York: Oxford University Press.

Ikiara, M. M. (1999). Sustainability, livelihoods, production and efforts supply in a declining fishery: The case of Kenya's lake Victoria Fisheries. The Netherlands: University of Amsterdam.

Kamotho, K. (2000, November 11). Millions of girls still missing in schools. The East African Standard. Nairobi: The East African Standard Publishers, p. 13.

Kayongo-Male, D. \& Walji, P. (1984). Children at work in Kenya. Nairobi: Oxford University Press.

Kayongo-Male, D. \& Onyango, P. (1991). The Sociology of the African Family. New York: Longman

Njue, L. (2000, July 28). Four million Kenyan kids in child Labour. The East Africa Standard. Nairobi: East African Standard Publishers, p. 4.

Ochieng', J. P. (1999, September). Child labour as a social conflict in Africa. Paper presented at the meeting of the Historical Association of Kenya. Kisumu, Kenya.

Ojwang', A. (2000, November 13). Trapped in lake Victoria. The East African Standard Nairobi: The East African Standard Magazine Publishers, p. 2.

Oloo, M. \& Ojwang', S. (1994): A summary statement reporting on drama activities in Homa-Bay addressing child labour. Unpublished Report. ANPPCAN.

Olweya, J. A. (1996). Education wastage among girls secondary schools: A case of Homa Bay district, Kenya, Unpublished master's thesis, Moi University, Eldoret, Kenya.

Onyango, P. (1988). Combating child labour. Geneva: ILO.

Otieno, C. (1995). Child labour in Kenya. ANPPCAN magazine, 21, September.

Shah, D. M. \& Cantwell, N. (Eds.). (1985). Child labour: A threat to health and development. Geneva: Defence for Children International Press.

Staff, (1997, January, 30). Child labour threatens the lives of hundreds. Daily Nation. 
Nairobi: Daily Nation Publishers, p. 25.

Staff, (1997, May 3). Parents to blame for child labour. Kenya Times. Nairobi: Kenya Times Publishers, p. 18.

Staff, (1997, July 29). Child labour persists despite strong lobbying. Daily Nation. Nairobi: Daily Nation Publishers, p. 17.

Staff, (1998, May 2). Minister's Labour Day gift. Daily Nation. Nairobi: Daily Nation Publishers, p. 2.

Staff, (1998, July 29). Over 50 per cent of those in fishing related activities in West Kenya are kids. Kenya Times. Nairobi: Kenya Times Publishers, p. 12.

Staff, (1998, September 25). Education levels cause concern. Daily Nation. Nairobi: Daily Nation Publishers, p. 27.

Staff, (2000, June 28). PS speaks on child labour. Daily Nation. Nairobi: Daily Nation Publishers, p. 2.

Staff, (2000, October 30). Child labour evil but poverty culprit. The People. Nairobi: The People Daily Publishers, p. 6.

UNESCO (1975). Women :Education Equality. Paris: IBE.

UNICEF (1992). Education sector adjustment credit: Situation analysis. Nairobi: UNICEF.

UNICEF, 1996. The State of the World's Children. New York: Oxford University Press. 